九州大学学術情報リポジトリ

Kyushu University Institutional Repository

\title{
Status of Oak Mushroom Cultivation and Production in Korea Focused on Hwasung and Yongin Cities in Gyeongg i Province
}

Lee, Sang Hyun

Faculty of Forest Science, Chonbuk National University

Kang, Hag Mo

Gyeonggi-do Forest Environment Research Station

Choi, Soo Im

Korea Forest Research Institute

Lee, Chang Heon

Faculty of Forest Science, Chonbuk National University

他

https://doi.org/10.5109/9310

出版情報：九州大学大学院農学研究院紀要. 52 (1)，pp.239-247，2007-02-28. Faculty of Agriculture, Kyushu University

バージョン：

権利関係： 


\title{
Status of Oak Mushroom Cultivation and Production in Korea Focused on Hwasung and Yongin Cities in Gyeonggi Province
}

\author{
Sang Hyun LEE ${ }^{1}$, Hag Mo KANG ${ }^{2 *}$, Soo Im $\mathrm{CHOI}^{3}$, Chang Heon $\mathrm{LEE}^{1}$, \\ Hyun Kim ${ }^{1}$, Young Jin $\mathrm{CHO}^{1}$, Ho Sub LIM ${ }^{1}$ \\ and Katsuhisa KOHROKI
}

\author{
Laboratory of Forest Policy, Division of Forest Environment and Management Sciences, \\ Department of Forest and Forest Products Sciences, Faculty of Agriculture, \\ Kyushu University, Fukuoka 812-8581, Japan \\ (Received November 9, 2006 and accepted December 1, 2006)
}

\begin{abstract}
The overall production of oak mushrooms has steadily increased in Korea, but the mushroom market is plagued with a wave of falling prices and intensified competition as imports of Chinese oak mushrooms increase. Imported Chinese oak mushrooms are mostly grown on sawdust blocks, which are costly in Korea because of higher labor costs and log prices. Mushroom farmers, therefore, strive to seek ways to compete with Chinese oak mushrooms, and the use of broad-leaved tree species is under consideration to promote sawdust-based mushroom cultivation. Korean oak mushrooms are expected to be more competitive when they are grown on sawdust rather than log while imports of Chinese mushrooms are still limited due to difficulties sustaining freshness. However, there are some obstacles such as the acquisition of superior strains of mushroom to promote sawdust cultivation of oak mushroom. Thus, The study investigated the status of production and sales of oak mushroom and the intent of mushroom farmers toward mushroom culture in wooden trays by conducting a questionnaire survey involving mushroom farmers in the two cities in Gyeonggi Province.

Results of the study revealed that there were differences in production volume and revenue per oak log between mushroom farmers in the two areas. Many farmers showed distrustful reactions towards strains distributed because of frequent loss and damages caused by purchased strains. It is, therefore, necessary to encourage farmers to increase productivity by standardizing culture techniques and supplying good strains of mushrooms. More farmers in Hwasung City are interested in mushroom cultivation in wooden trays, but farmers in Yongin City were less enthusiastic about mushroom cultivation in wooden trays after witnessing failures of other farmers. The findings of the study signifies the need for introducing effects of mushroom culture in wooden trays among mushroom farmers, and developing superior strains of mushrooms to promote mushroom growth using wooden trays.
\end{abstract}

\section{INTRODUCTION}

Mushroom production accounted for $7.4 \%$ of total revenue of 32.59 billion won generated from forest products in Korea in 2004. When the net growth of trees is excluded, mushroom production accounted for $20.5 \%$ of total revenue, indicating the second largest source of income, next to revenue of 66.722 billion won generated from garden trees (Korea Forest Service, 2005). Thus, mushroom production has become a growing income generator in rural areas since it was strategically promoted by the government since 1970. The number of households growing mushrooms reached about 9,200 across the nation as of 2004, and the total land used for mushroom production was 2,600 ha in the same year.

However, mushroom farmers are facing an array of challenges, including unstable supply of logs, strains of mushrooms, price declines as a result of overproduction of mushrooms, and increased imports of Chinese mushrooms (Kang et al., 2005; Lee, 1996). A large number of

\footnotetext{
Faculty of Forest Science, Chonbuk National University, Chonju, 561-756, Korea

Gyeonggi-do Forest Environment Research Station, Osan, 447-290, Korea

Korea Forest Research Institute, Seoul, 130-712, Korea

* Corresponding author (E-mail: kanghagmo@hanmail.net)
}

studies have addressed the prevention of insecticides, fungal contamination, optimized cultivation environment and technologies, and development of superior strains of mushrooms. But there are not many evidence-based studies on oak mushroom farmers. The purpose of this study was to investigate the status of production, and sales of oak mushrooms in the two cities known for mushroom production in Gyeonggi province and their intent toward mushroom culture in wooden trays to suggest future directions in mushroom cultivation.

\section{METHODS}

Firstly, the study addressed the number of households growing mushrooms, the amount of mushrooms produced by these farmers, and the amounts of mushrooms imported and exported in Korea to estimate the nationwide data on mushroom production. Also, the general status of cultivation of mushroom was looked over in Gyeonggi Province, where the investigated regions exist. A questionnaire was administered to 20 mushroom growing households in Hwasung City and 13 mushroom growing households in Yongin City, and respondents completed the questionnaire through direct interview during the period from July 2004 to August 2004. The questionnaire covered labor composition in each household, a land size used for farming, revenue in 
relation to reproduction process, the number of oak logs per year, the number of oak logs by the type of mushroom, the amount of oak mushrooms produced and sales of oak mushroom, the volume of future mushroom cultivation, plan for mushroom culture using wooden trays and overall production, and management plan for mushroom cultivation. Collected data were analyzed by age of respondents, the size of land, the size of cultivation and region.

\section{RESULTS AND DISCUSSION}

\section{Status of Oak Mushroom Cultivation and Production in Korea}

Oak mushroom production has been strategically promoted since 1970 s, leading to a steady increase in production. The number of mushroom growing households reached about 9,200 in 2004. Of those, about 60\% are based in South Chungchung, South Jeolla and North Gyeongsang Provinces. The total area used for mushroom cultivation is 2,600 ha. Of total area, more than $60 \%$ was used for growing mushrooms in a growing structure. Only 20 households used wooden trays for mushroom culture (Table 1).

Oak mushroom production has increased every year, leading to about 20,000 tons in 2000 and 26,000 tons in 2004. By amount, total revenue increased to 240 billion won in 2004 from 160 billion won in 2000. The sales of fresh mushrooms outpaced that of dried mushrooms (Korea Forest Service, 2005) (Table 2).

Table 1. Status of mushroom growing households and cultivation (as of 2004)

Unit: household

\begin{tabular}{|c|c|c|c|c|c|}
\hline \multirow[b]{2}{*}{ Province } & \multirow{2}{*}{$\begin{array}{l}\text { Mushroom } \\
\text { growing } \\
\text { households }\end{array}$} & \multicolumn{3}{|c|}{ Cultivation Type(ha) } & \multirow[b]{2}{*}{ Wooden Trays } \\
\hline & & Total & $\begin{array}{l}\text { Growing } \\
\text { structure }\end{array}$ & $\begin{array}{l}\text { Outdoor } \\
\text { culture }\end{array}$ & \\
\hline Total & $\begin{array}{c}9,189 \\
(100.0)\end{array}$ & $\begin{array}{l}2,616.5 \\
(100.0)\end{array}$ & $\begin{array}{c}1,654.0 \\
(63.2)\end{array}$ & $\begin{array}{l}962.5 \\
(36.8) \\
\end{array}$ & 20 \\
\hline South Choong-chung & $\begin{array}{l}2,833 \\
(30.8)\end{array}$ & $\begin{array}{r}731.9 \\
(100.0)\end{array}$ & $\begin{array}{l}485.3 \\
(66.3)\end{array}$ & $\begin{array}{l}246.6 \\
(33.7)\end{array}$ & 2 \\
\hline South Jeolla & $\begin{array}{r}1,672 \\
(18.2)\end{array}$ & $\begin{array}{r}719.9 \\
(100.0)\end{array}$ & $\begin{array}{r}25.2 \\
(39.6)\end{array}$ & $\begin{array}{c}434.7 \\
(60.4)\end{array}$ & 2 \\
\hline North Gyeongsang & $\begin{array}{c}1,094 \\
(11.9)\end{array}$ & $\begin{array}{r}329.8 \\
(100.0)\end{array}$ & $\begin{array}{l}321.7 \\
(97.6)\end{array}$ & $\begin{array}{r}8.1 \\
(2.4)\end{array}$ & 3 \\
\hline Gyeonggi & $\begin{array}{r}855 \\
(9.3)\end{array}$ & $\begin{array}{r}225.9 \\
(100.0)\end{array}$ & $\begin{array}{l}202.7 \\
(89.7)\end{array}$ & $\begin{array}{r}23.2 \\
(10.3)\end{array}$ & 4 \\
\hline North Jeolla & $\begin{array}{r}726 \\
(7.9)\end{array}$ & $\begin{array}{r}65.6 \\
(100.0)\end{array}$ & $\begin{array}{r}47.5 \\
(72.4)\end{array}$ & $\begin{array}{r}18.1 \\
(27.6)\end{array}$ & - \\
\hline South Gyeongsang & $\begin{array}{r}719 \\
(7.8)\end{array}$ & $\begin{array}{r}156.1 \\
(100.0)\end{array}$ & $\begin{array}{r}67.6 \\
(43.3)\end{array}$ & $\begin{array}{r}88.5 \\
(56.7)\end{array}$ & 4 \\
\hline North Choong-chung & $\begin{array}{r}699 \\
(7.6)\end{array}$ & $\begin{array}{r}187.7 \\
(100.0)\end{array}$ & $\begin{array}{l}174.4 \\
(92.9)\end{array}$ & $\begin{array}{c}13.3 \\
(7.1)\end{array}$ & 2 \\
\hline Kwangwon & $\begin{array}{r}384 \\
(4.2)\end{array}$ & $\begin{array}{r}57.2 \\
(100.0)\end{array}$ & $\begin{array}{r}45.0 \\
(78.7)\end{array}$ & $\begin{array}{r}12.2 \\
(21.3)\end{array}$ & 3 \\
\hline Others & $\begin{array}{r}205 \\
(2.2) \\
\end{array}$ & $\begin{array}{r}142.5 \\
(100.0)\end{array}$ & $\begin{array}{r}24.6 \\
(17.3) \\
\end{array}$ & $\begin{array}{r}117.9 \\
(82.7) \\
\end{array}$ & - \\
\hline
\end{tabular}

Note: Figure in a parenthesis indicates a composition ratio (\%)

Source: Korea Forest Research Institute. 2004 Recent state of mushroom production

Table 2. Status of oak mushrooms production in Korea

\begin{tabular}{|c|c|c|c|c|c|c|}
\hline \multirow[b]{2}{*}{ Year } & \multicolumn{3}{|c|}{ Quantity } & \multicolumn{3}{|c|}{ Amount } \\
\hline & $\begin{array}{c}\text { Total } \\
\text { (tons) }\end{array}$ & $\begin{array}{c}\text { Dried } \\
\text { Mushrooms } \\
\text { (tons) }\end{array}$ & $\begin{array}{c}\text { Fresh } \\
\text { Mushrooms } \\
\text { (tons) }\end{array}$ & $\begin{array}{c}\text { Total } \\
\text { (100 million } \\
\text { won) }\end{array}$ & $\begin{array}{c}\text { Dried } \\
\text { (100 million } \\
\text { won) }\end{array}$ & $\begin{array}{c}\text { Fresh } \\
\text { (100 million } \\
\text { won) }\end{array}$ \\
\hline 2000 & $\begin{array}{c}19,732.4 \\
(100.0)\end{array}$ & $\begin{array}{c}2,278.0 \\
(11.5)\end{array}$ & $\begin{array}{c}17,454.4 \\
(88.5)\end{array}$ & $\begin{array}{l}1,609.9 \\
(100.0)\end{array}$ & $\begin{array}{l}570.7 \\
(35.4)\end{array}$ & $\begin{array}{c}1,039.2 \\
(64.6)\end{array}$ \\
\hline 2001 & $\begin{array}{c}20,741.1 \\
(100.0)\end{array}$ & $\begin{array}{c}2,222.9 \\
(10.7)\end{array}$ & $\begin{array}{c}18,518.2 \\
(89.3)\end{array}$ & $\begin{array}{l}1,648.4 \\
(100.0)\end{array}$ & $\begin{array}{l}535.5 \\
(32.5)\end{array}$ & $\begin{array}{c}1,112.9 \\
(67.5)\end{array}$ \\
\hline 2002 & $\begin{array}{c}23,776.4 \\
(100.0)\end{array}$ & $\begin{array}{c}2,231.0 \\
(9.4)\end{array}$ & $\begin{array}{c}21,545.4 \\
(90.6)\end{array}$ & $\begin{array}{l}2,043.6 \\
(100.0)\end{array}$ & $\begin{array}{l}624.2 \\
(30.5)\end{array}$ & $\begin{array}{c}1,419.4 \\
(69.5)\end{array}$ \\
\hline 2003 & $\begin{array}{c}24,311.1 \\
(100.0)\end{array}$ & $\begin{array}{c}1,936.9 \\
(8.0)\end{array}$ & $\begin{array}{c}22,374.2 \\
(92.0)\end{array}$ & $\begin{array}{l}2,361.9 \\
(100.0)\end{array}$ & $\begin{array}{l}524.9 \\
(22.2)\end{array}$ & $\begin{array}{c}1,837.0 \\
(77.8)\end{array}$ \\
\hline 2004 & $\begin{array}{c}26,318.9 \\
(100.0)\end{array}$ & $\begin{array}{c}1,921.6 \\
(7.3)\end{array}$ & $\begin{array}{c}24,397.3 \\
(92.7)\end{array}$ & $\begin{array}{l}2,425.0 \\
(100.0)\end{array}$ & $\begin{array}{l}529.2 \\
(21.8)\end{array}$ & $\begin{array}{c}1,895.8 \\
(78.2)\end{array}$ \\
\hline
\end{tabular}

Note: Figure in a parenthesis indicates a composition ratio (\%)

Source: Korea Forest Service. 2005 Statistical yearbook of forestry 
Exports of oak mushrooms increased by 350 tons in 2004, compared with exports of 228 tons in 2000, whereas imported oak mushrooms increased eight times as much as exported mushrooms. Oak mushroom imports tripled over 2000-2004, showing a steep increase in imports of processed mushrooms. By country, Japan was the biggest importer of Korean oak mushrooms and purchased 53\% of total imports in 2002 and $63 \%$ in 2003, respectively. Almost all (99\%) of oak mushrooms were imported from China. Sluggish exports of oak mushrooms are attributed to higher prices than those of Chinese oak mushrooms (Korea Forest Research Institute, 2004; Korea Forest Service, 2006) (Table 3).

\section{Investigation of Oak Mushroom Cultivation in Gyeonggi Province}

There were 855 oak mushroom growing households in 20 among 31cities and countries in Gyeonggi Province as of 2004. These households produced both dried $(34,000 \mathrm{~kg})$ and fresh (3.38 million $\mathrm{kg})$ oak mushrooms in 2004, making up $1.8 \%$ and $13.9 \%$ of total mushrooms produced nationwide. By amount, they produced dried oak mushrooms worth 900 million won and fresh mushrooms worth 4.7 billion won, making up 1.7\% and $24.8 \%$ of total revenue generated nationwide, respectively. By city, 109 households were based in Hwasung and 36 households in Yongin. The former had the total cultivation area of 74 ha with the number of oak logs of 1.2 million and the latter had 37 ha with the number of oak logs of 750,000 (Gyeonggi Province, 2005).

\section{Reproduction Structure}

Labor Composition

A total of 92 members were in the over 20 years age group in 33 households combined, and an average number was 2.8 per household. In Hwasung City, an average number was 2.8 per household and an average age of household was 55 years. By age group, those in their 60 s was the largest group, constituting 25\% of total members of all households. In Yongin City, an average number was 2.8 per household and an average age of households was 51 years. Those in their 50's were the largest group comprising $28 \%$ of total members (Table 4).

\section{Status of Farming Area}

Of 33 households, 6 (18\%) did not own their land, but the remaining 27 households used the area of 56.9 ha for farming. Of 33 households, 14 owned forest, and an average size of their forest was 1.3 ha. Of those,

Table 3. Exports and imports of oak mushrooms

\begin{tabular}{ccccccc} 
Table 3. Exports and imports of oak mushrooms & \multicolumn{3}{c}{} & Unit: tons \\
\hline \multirow{4}{*}{ Exports } & Year & Total & $\begin{array}{c}\text { Dried } \\
\text { mushrooms }\end{array}$ & $\begin{array}{c}\text { Fresh } \\
\text { mushrooms }\end{array}$ & $\begin{array}{c}\text { Processed } \\
\text { mushrooms }\end{array}$ & $\begin{array}{c}\text { Amount } \\
\text { (U\$ 000) }\end{array}$ \\
\cline { 2 - 7 } & 2000 & 227.6 & 226.1 & 0.3 & 1.5 & $5,012.0$ \\
& 2001 & 202.9 & 191.4 & 67.7 & 1.9 & $4,376.0$ \\
& 2002 & 259.6 & 254.4 & 36.5 & - & $4,306.0$ \\
Imports & 2003 & 363.9 & 362.1 & 12.2 & - & $6,403.0$ \\
& 2004 & 235.0 & 235.0 & - & - & $4,583.0$ \\
& 2005 & 350.0 & 349.0 & 1.0 & - & $4,870.0$ \\
& 2000 & $1,088.5$ & $1,079.0$ & 58.8 & 1.3 & $2,738.0$ \\
& 2001 & 820.9 & 811.9 & 50.9 & 1.9 & $1,914.0$ \\
& 2002 & $1,232.1$ & 905.4 & 7.7 & 325.6 & $2,575.0$ \\
& 2003 & $1,926.2$ & 999.6 & - & 926.6 & $3,834.0$ \\
& 2004 & $2,979.1$ & $1,254.0$ & 115.0 & $1,709.0$ & $5,173.0$ \\
& 2005 & $3,508.9$ & $1,080.0$ & 335.0 & $2,382.0$ & $5,588.0$
\end{tabular}

Note: 1) Figure in a parenthesis indicates a composition ratio (\%)

2) Total $=$ Dried $+($ fresh $* 0.14)+$ Processed mushrooms

Source: 1) Korea Forest Research Institute. 2004 Recent state of mushroom production

2) Korea Forest Service. 2006 Export and import statistics on forest products

Table 4. Household labor composition

Unit: number of people

\begin{tabular}{|c|c|c|c|c|c|c|c|c|c|}
\hline \multirow{2}{*}{ Households } & \multicolumn{3}{|c|}{ Total } & \multirow{2}{*}{20 's } & \multirow{2}{*}{ 30's } & \multirow{2}{*}{40 's } & \multirow{2}{*}{50 's } & \multirow{2}{*}{ 60's } & \multirow{2}{*}{$\begin{array}{c}\text { Over } 70 \\
\text { years }\end{array}$} \\
\hline & Total & Male & Female & & & & & & \\
\hline $\begin{array}{l}\text { Total } \\
(33)\end{array}$ & 92 & 45 & 47 & 10 & 12 & 19 & 20 & 19 & 12 \\
\hline $\begin{array}{l}\text { Hwasung } \\
\text { (20) }\end{array}$ & $\begin{array}{c}56 \\
(100.0)\end{array}$ & 27 & 29 & $\begin{array}{c}6 \\
(10.7)\end{array}$ & $\begin{array}{c}8 \\
(14.3)\end{array}$ & $\begin{array}{c}10 \\
(17.9)\end{array}$ & $\begin{array}{c}10 \\
(17.9)\end{array}$ & $\begin{array}{c}14 \\
(25.0)\end{array}$ & $\begin{array}{c}8 \\
(14.3)\end{array}$ \\
\hline $\begin{array}{l}\text { Yongin } \\
\text { (13) }\end{array}$ & $\begin{array}{c}36 \\
(100.0)\end{array}$ & 18 & 18 & $\begin{array}{c}4 \\
(11.1)\end{array}$ & $\begin{array}{c}4 \\
(11.1)\end{array}$ & $\begin{array}{c}9 \\
(25.0)\end{array}$ & $\begin{array}{c}10 \\
(27.8)\end{array}$ & $\begin{array}{c}5 \\
(13.9)\end{array}$ & $\begin{array}{c}4 \\
(11.1)\end{array}$ \\
\hline
\end{tabular}

Note: 1) Figure in a parenthesis indicates a composition ratio (\%)

2) Those under 20 years were not counted 
5 households secured logs from their forest, and 1 household used the forest for mush cultivation. In Hwasung, an average farming area was 2.7 ha, compared to 0.8 ha in Yongin. There were 9 households grew mushrooms in a land that is larger than 2 ha. Two households owned forest. One of them plan to secure 3,000 logs in its forest (Table 5).

Status of Household Income

Table 5. Status of areas used for cultivation

\begin{tabular}{|c|c|c|c|c|c|c|c|c|c|}
\hline City & $\begin{array}{c}\text { Total } \\
\text { (households) }\end{array}$ & Avg/household & no land & $\begin{array}{c}\text { Less than } \\
0.5 \text { ha }\end{array}$ & $\begin{array}{l}0.5- \\
1.0 \text { ha }\end{array}$ & $\begin{array}{c}1.0- \\
1.5 \mathrm{ha}\end{array}$ & $\begin{array}{c}1.5- \\
2.0 \text { ha }\end{array}$ & $\begin{array}{c}\text { More than } \\
2.0 \text { ha }\end{array}$ & Forest \\
\hline Total & $\begin{array}{l}56.9 \\
(33)\end{array}$ & $\begin{array}{c}2.1 \\
(27)\end{array}$ & (6) & $\begin{array}{l}0.7 \\
(3)\end{array}$ & $\begin{array}{l}3.9 \\
(6)\end{array}$ & $\begin{array}{l}2.0 \\
(2)\end{array}$ & $\begin{array}{l}17.8 \\
(7)\end{array}$ & $\begin{array}{c}32.5 \\
(9)\end{array}$ & $\begin{array}{l}17.5 \\
(14)\end{array}$ \\
\hline Hwasung & $\begin{array}{l}49.4 \\
(20)\end{array}$ & $\begin{array}{c}2.7 \\
(18)\end{array}$ & (2) & $\begin{array}{l}0.2 \\
(1)\end{array}$ & $\begin{array}{l}1.2 \\
(2)\end{array}$ & $\begin{array}{l}1.0 \\
(1)\end{array}$ & $\begin{array}{l}14.5 \\
(5)\end{array}$ & $\begin{array}{c}32.5 \\
(9)\end{array}$ & $\begin{array}{l}16.5 \\
(12)\end{array}$ \\
\hline Yongin & $\begin{array}{r}7.5 \\
(13)\end{array}$ & $\begin{array}{l}0.8 \\
(9)\end{array}$ & (4) & $\begin{array}{l}0.5 \\
(2)\end{array}$ & $\begin{array}{l}2.7 \\
(4)\end{array}$ & $\begin{array}{l}1.0 \\
(1)\end{array}$ & $\begin{array}{l}3.3 \\
(2)\end{array}$ & - & $\begin{array}{l}1.0 \\
(2)\end{array}$ \\
\hline
\end{tabular}

Note: 1) Figure in a parenthesis indicates the number of households

2) Forests were not included in Total

Table 6. Income sources of mushroom growing households

Unit: million won

\begin{tabular}{|c|c|c|c|c|c|c|c|c|c|c|c|}
\hline & Category & & $\begin{array}{l}\text { House } \\
\text {-holds }\end{array}$ & Total & $\begin{array}{l}\text { House- } \\
\text { hold avg. }\end{array}$ & $\begin{array}{l}\text { Oak } \\
\text { mush- } \\
\text { room }\end{array}$ & $\begin{array}{l}\text { Agri- } \\
\text { cultural } \\
\text { farming }\end{array}$ & $\begin{array}{l}\text { Fruits } \\
\text { trees }\end{array}$ & $\begin{array}{c}\text { Temporary } \\
\text { labor } \\
\text { work }\end{array}$ & $\begin{array}{c}\text { Fulltime } \\
\text { labor } \\
\text { work }\end{array}$ & Others \\
\hline \multirow{17}{*}{$\begin{array}{l}\text { Hwa- } \\
\text { sung }\end{array}$} & & Total & 20 & $\begin{array}{c}959.7 \\
(100.0)\end{array}$ & 48.0 & $\begin{array}{r}576.4 \\
(60.0) \\
\end{array}$ & $\begin{array}{c}\text { a278.4 } \\
(29.0)\end{array}$ & $\begin{array}{l}53.0 \\
(5.5) \\
\end{array}$ & $\begin{array}{l}26.6 \\
(2.8) \\
\end{array}$ & $\begin{array}{l}11.2 \\
(1.2) \\
\end{array}$ & $\begin{array}{c}14.1 \\
(1.2) \\
\end{array}$ \\
\hline & \multirow{5}{*}{ Age } & 30 's & 2 & 146.0 & 73.0 & 91.0 & 45.0 & - & 10.0 & - & - \\
\hline & & 40's & 5 & 288.2 & 97.6 & 130.0 & 82.2 & 53.0 & 13.0 & 10.0 & - \\
\hline & & 50 's & 6 & 332.5 & 55.4 & 272.0 & 57.2 & - & 2.1 & 1.2 & 13.5 \\
\hline & & 60's & 4 & 167.5 & 41.9 & 65.4 & 87.1 & - & 1.5 & - & 0.6 \\
\hline & & Over 70 & 3 & 25.5 & 8.5 & 18.0 & 6.9 & - & - & - & - \\
\hline & \multirow{6}{*}{$\begin{array}{c}\text { Farming } \\
\text { area }\end{array}$} & No land & 2 & 245.0 & 122.5 & 245.0 & - & - & - & - & 0.6 \\
\hline & & Less than 0.5 ha & 1 & 3.6 & 3.6 & 3.0 & - & - & - & - & - \\
\hline & & 0.5-1.0 ha & 2 & 22.4 & 11.2 & 16.0 & 6.0 & - & 0.4 & - & - \\
\hline & & $1.0-1.5 \mathrm{ha}$ & 1 & 11.6 & 11.6 & 3.0 & 5.6 & - & 1.8 & 1.2 & - \\
\hline & & 1.5-2.0 ha & 5 & 142.5 & 28.5 & 45.0 & 77.5 & - & 10.0 & 10.0 & - \\
\hline & & More than 2.0 ha & 9 & 534.7 & 53.5 & 264. & 189.3 & 53.0 & 14.5 & - & 13.5 \\
\hline & \multirow{6}{*}{$\begin{array}{c}\text { Number } \\
\text { of oak } \\
\operatorname{logs}\end{array}$} & Less than 10,000 & 11 & 269.6 & 24.5 & 84.0 & 162.0 & - & 11.8 & 11.2 & 0.6 \\
\hline & & $10,000-20,000$ & 3 & 103.0 & 34.3 & 57.4 & 30.2 & - & 1.9 & - & 13.5 \\
\hline & & $20,000-30,000$ & 3 & 171.2 & 57.1 & 85.0 & 33.2 & 53.0 & - & - & - \\
\hline & & $30,000-40,000$ & 1 & 135.0 & 135.0 & 90.0 & 35.0 & - & 10.0 & - & - \\
\hline & & More than 40,000 & 2 & 281.0 & 140.5 & 260.0 & 18.0 & - & 3.0 & - & - \\
\hline \multirow{15}{*}{ Yongin } & & Total & $\begin{array}{c}13 \\
(11)\end{array}$ & $\begin{array}{c}476.2 \\
(100.0)\end{array}$ & 43.3 & $\begin{array}{l}383.0 \\
(80.4)\end{array}$ & $\begin{array}{l}24.8 \\
(5.2)\end{array}$ & - & $\begin{array}{c}2.6 \\
(0.5)\end{array}$ & $\begin{array}{c}58.0 \\
(12.2)\end{array}$ & $\begin{array}{c}7.8 \\
(1.6)\end{array}$ \\
\hline & \multirow{4}{*}{ Age } & 30's & 1 & 44.8 & 44.8 & 25.0 & - & - & - & 16.0 & 3.8 \\
\hline & & 40's & $5(4)$ & 179.1 & 44.8 & 165.0 & 11.5 & - & 2.6 & - & - \\
\hline & & 50 's & 5 & 213.3 & 42.7 & 177.0 & 5.3 & - & - & 27.0 & 4.0 \\
\hline & & 60 's & $2(1)$ & 39.0 & 39.0 & 16.0 & 8.0 & - & - & 15.0 & - \\
\hline & \multirow{5}{*}{$\begin{array}{c}\text { Farming } \\
\text { area }\end{array}$} & No land & 4 & 235.0 & 58.8 & 235.0 & - & - & - & - & - \\
\hline & & Less than 0.5 & $2(1)$ & 41.9 & 41.9 & 30.0 & 1.9 & - & - & 10.0 & - \\
\hline & & $0.5-1.0$ ha & $4(3)$ & 131.2 & 43.7 & 87.0 & 3.4 & - & - & 33.0 & 7.8 \\
\hline & & $1.0-1.5 \mathrm{ha}$ & 1 & 10.1 & 10.1 & 5.0 & 3.5 & - & 1.6 & - & - \\
\hline & & 1.5-2.0 ha & 2 & 58.0 & 29.0 & 26.0 & 16.0 & - & 1.0 & 15.0 & - \\
\hline & \multirow{5}{*}{$\begin{array}{c}\text { Number } \\
\text { of oak } \\
\text { logs }\end{array}$} & Less than 10,000 & 2 & 29.1 & 14.6 & 15.0 & 11.5 & - & 2.6 & - & - \\
\hline & & $10,000-20,000$ & 2 & 64.0 & 32.0 & 41.0 & 8.0 & - & - & 15.0 & - \\
\hline & & $20,000-30,000$ & $6(5)$ & 223.1 & 44.6 & 167.0 & 5.3 & - & - & 43.0 & 7.8 \\
\hline & & $30,000-40,000$ & $1(0)$ & - & - & - & - & - & - & - & - \\
\hline & & More than 40,000 & 2 & 160.0 & 80.0 & 160.0 & - & - & - & - & - \\
\hline
\end{tabular}

Note: 1) Figure in a parenthesis indicates a composition ratio (\%)

2) Others include interests, livestock income, rental income and beekeeping income

3) Two households in Yongin did not reveal their mushroom income so not included in the calculation of total and average income 
The household income was 48 million won on average in Hwasung. Oak mushroom production contributed to $60 \%$ of the income and agricultural farming generated $29 \%$ of the income. The younger mushroom growers along with those with a bigger farming area and those with a larger production volume of mushrooms made a higher income. In Yongin, the household income was 43 million won, $80 \%$ of which was generated from oak mushroom cultivation and $12 \%$ was derived from full-time labor work. Thus, the level of income generated from mushroom cultivation was higher in Yongin.

Those in their 30's to 50's, those with a farming area of more than 2 ha and those with oak logs of 20,000 to 30,000 had higher levels of income than others in Hwasung. Those in their 30's and 40's and those with oak logs of 20,000 to 30,000 had higher levels of income in Yongin. An average income of households was 29 million won in rural areas and 37 million won in urban areas in Korea in 2004(Ministry of Agriculture and Forestry, 2005) (Table 6).

Management Plans for Forestry and Agricultural Farming

Of 20 households in Hwasung, 11 cited mushroom cultivation and 9 cited agricultural farming as the major source of income. The older age groups, those with a large farming area and those who grow mushrooms on a small scale said the majority of their household income is derived from agricultural farming. As for farming area, 11 households plan to expand their farming land and 9 plan to sustain the current level. As for forest, 7 households plan to expand and 13 plan to sustain the current level. There are 4 households in which descendants are ready to take over family business. The reason of expanding their farming area was for financially stable. Those who wanted to maintain the current farming area cited labor shortage as the main reason. Those who wanted to have a larger forest cited an increase in mushroom cultivation, supply of logs, an increase in wealth and more grave spaces as main reasons. In Yongin, of 13 households, 12 said mushroom cultivation would become a major source of income in the future. As for farming area, 11 households plan to expand and 2 plan to sustain the current level. As for forest, 11 households plan to increase and 2 plan to maintain the current level. There was 1 household in which a descendant plans to take over family business (Table 7). Those who want to expand their farming areas cited an increase in oak mushroom cultivation as the main reason. Of households who want to increase their ownership on forest, 8 cited an expansion in mushroom cultivation, and two citied an increase in wealth as the main reason.

Status of Cultivation and Production of Oak Mushrooms

Number of Oak Logs

Each mushroom growing household had about 18,000 mushrooms logs on average in Hwasung. By age,

Table 7. Plans for forestry and agricultural farming Unit: household

\begin{tabular}{|c|c|c|c|c|c|c|c|c|c|c|c|c|}
\hline & \multirow{2}{*}{\multicolumn{2}{|c|}{ Category }} & \multirow[b]{2}{*}{$\begin{array}{l}\text { House } \\
\text {-holds }\end{array}$} & \multicolumn{3}{|c|}{ Major source of income } & \multicolumn{2}{|c|}{ Farming area } & \multicolumn{2}{|c|}{ Forest } & \multicolumn{2}{|c|}{ Heirs } \\
\hline & & & & $\begin{array}{c}\text { Oak } \\
\text { mush } \\
\text {-room }\end{array}$ & $\begin{array}{l}\text { Agri- } \\
\text { cultural } \\
\text { farming }\end{array}$ & $\begin{array}{c}\text { Full-time } \\
\text { labor } \\
\text { work }\end{array}$ & $\begin{array}{l}\text { Expan } \\
\text {-sion }\end{array}$ & $\begin{array}{c}\text { No } \\
\text { change }\end{array}$ & $\begin{array}{l}\text { Expan } \\
\text {-sion }\end{array}$ & $\begin{array}{c}\text { No } \\
\text { change }\end{array}$ & Heir & $\begin{array}{l}\text { No } \\
\text { heir }\end{array}$ \\
\hline \multirow{18}{*}{$\begin{array}{l}\text { Hwa- } \\
\text { sung }\end{array}$} & \multicolumn{2}{|r|}{ Total } & 20 & 11 & 9 & - & 11 & 9 & 7 & 13 & 4 & 16 \\
\hline & \multirow{5}{*}{ Age } & 30 's & 2 & 2 & - & - & 2 & - & 2 & - & - & 2 \\
\hline & & 40's & 5 & 5 & - & - & 5 & - & 3 & 2 & - & 5 \\
\hline & & 50 's & 6 & 2 & 4 & - & 3 & 3 & 2 & 4 & 3 & 3 \\
\hline & & 60's & 4 & & 4 & - & 1 & 3 & - & 4 & - & 4 \\
\hline & & Over 70 & 3 & 2 & 1 & - & & 3 & - & 3 & 1 & 2 \\
\hline & \multirow{6}{*}{$\begin{array}{c}\text { Farming } \\
\text { area }\end{array}$} & No land & 2 & 2 & - & - & 1 & 1 & 1 & 1 & 1 & 1 \\
\hline & & Less than 0.5 ha & 1 & 1 & - & - & - & 1 & - & 1 & - & 1 \\
\hline & & $0.5-1.0$ ha & 2 & 1 & 1 & - & & 2 & - & 2 & 2 & \\
\hline & & $1.0-1.5 \mathrm{ha}$ & 1 & & 1 & - & 1 & 1 & - & 1 & - & 1 \\
\hline & & 1.5-2.0 ha & 5 & 3 & 2 & - & 4 & 1 & 2 & 3 & 1 & 4 \\
\hline & & More than 2.0 ha & 9 & 4 & 5 & - & 5 & 4 & 4 & 5 & - & 9 \\
\hline & \multirow{6}{*}{$\begin{array}{c}\text { Number } \\
\text { of oak } \\
\text { logs }\end{array}$} & Less than 10,000 & 11 & 5 & 6 & - & 6 & 5 & 2 & 9 & 2 & 9 \\
\hline & & $10,000-20,000$ & 3 & - & 3 & - & - & 3 & - & 3 & 1 & 2 \\
\hline & & $20,000-30,000$ & 3 & 3 & - & - & 3 & - & 3 & - & - & 3 \\
\hline & & $30,000-40,000$ & 1 & 1 & - & - & 1 & - & 1 & - & - & 1 \\
\hline & & More than 40,000 & 2 & 2 & - & - & 1 & 1 & 1 & 1 & 1 & 1 \\
\hline & & Total & 13 & 12 & - & 1 & 11 & 2 & 11 & 2 & 1 & 12 \\
\hline \multirow{5}{*}{ Yongin } & \multirow{5}{*}{$\begin{array}{c}\text { Number } \\
\text { of oak } \\
\text { logs }\end{array}$} & Less than 10,000 & 2 & 2 & - & - & 2 & - & 1 & 1 & - & 2 \\
\hline & & $10,000-20,000$ & 2 & 2 & - & - & 1 & 1 & 2 & - & - & 2 \\
\hline & & $20,000-30,000$ & 6 & 5 & - & 1 & 6 & - & 6 & - & - & 6 \\
\hline & & $30,000-40,000$ & 1 & 1 & - & - & - & 1 & - & 1 & - & 1 \\
\hline & & More than 40,000 & 2 & 2 & - & - & 2 & 2 & 2 & - & 1 & 1 \\
\hline
\end{tabular}


those in their 40's constituted the largest group of mushroom growers, followed by those in 50's and those in their 30's. A large number of households who did not own a farming land had a larger number of oak logs than the average. Of 20 households in Hwasung, 14 purchased logs from timber dealers and 8 paid fee to forest landowners to secure logs from their forest. But more mushroom farmers purchase logs at timber dealers due to various reasons, such as refusal of landowners and the distance between forest and cultivation area. Mushroom growers said it would be more than 50\% cheaper to obtain logs from forest than buying logs from timber dealers.

In Yongin, an average number of oak logs was 24,000 per household, which is larger than that of Hwasung. Those in their 30's and 50's and those who did not own a farming land had a larger number of oak logs than the average number (Table 8). Of 13 households, 12 had experience of obtaining logs directly from forest, and 7 households purchased logs from timber dealers. Mushroom growers in Yongin had the same difficulty as their peers in Hwasung obtaining logs from forest.

By the type of mushroom, the low temperature type of mushroom accounted for 64\% in Hwasung, followed by the high temperature type (29\%) and the medium temperature type $(7 \%)$. Those in the older age group, those with a large farming area and those with mushroom cultivation on a small scale grew the low temperature type of mushroom. The low temperature type of mushroom is favored when mushroom farmers relied on labor available during winter because it is hard workers in summer. The high-temperature type of mushrooms was chosen by those who wanted to cultivate mushrooms throughout the year. And it was possible for many mushroom growers to use labor available for agricultural farming given their small-scale mushroom cultivation. The medium temperature type of mushrooms accounted for 97\% of total mushrooms grown in Yongin City, followed the low temperature type of mushrooms (3\%) (Table 9). Farmers can grow the medium temperature type of mushrooms from March through October, and that is the biggest reason for preferring the medium temperature type. Respondents in Yongin cited the extra investment needed for cultivation of the low-temperature type as the main reason for avoiding the low temperature type.

Table 8. Number of oak logs by year

\begin{tabular}{|c|c|c|c|c|c|c|c|c|}
\hline City & Households & Total & $\begin{array}{c}\text { Household } \\
\text { Avg. }\end{array}$ & 1st year & 2nd year & 3rd year & 4 th year & $\begin{array}{c}\text { 5th year or } \\
\text { over }\end{array}$ \\
\hline Total & 33 & $\begin{array}{c}667.4 \\
(100.0)\end{array}$ & 20.2 & $\begin{array}{l}182.9 \\
(27.4)\end{array}$ & $\begin{array}{l}191.5 \\
(28.7)\end{array}$ & $\begin{array}{c}150.0 \\
(22.5)\end{array}$ & $\begin{array}{c}113.5 \\
(17.0)\end{array}$ & $\begin{array}{l}29.5 \\
(4.4)\end{array}$ \\
\hline Hwasung & 20 & $\begin{array}{c}358.4 \\
(100.0)\end{array}$ & 17.9 & $\begin{array}{c}87.4 \\
(24.4)\end{array}$ & $\begin{array}{c}97.0 \\
(27.1)\end{array}$ & $\begin{array}{c}82.5 \\
(23.0)\end{array}$ & $\begin{array}{c}75.5 \\
(21.1)\end{array}$ & $\begin{array}{l}16.0 \\
(4.5)\end{array}$ \\
\hline Yongin & 13 & $\begin{array}{c}309.0 \\
(100.0)\end{array}$ & 23.8 & $\begin{array}{c}95.5 \\
(30.9)\end{array}$ & $\begin{array}{c}94.5 \\
(30.6)\end{array}$ & $\begin{array}{c}67.5 \\
(21.8)\end{array}$ & $\begin{array}{c}38.0 \\
(12.3)\end{array}$ & $\begin{array}{l}13.5 \\
(4.4)\end{array}$ \\
\hline
\end{tabular}

Note: Figure in a parenthesis indicates a composition ratio (\%)

Table 9. Number of oak logs by the type of mushroom

\begin{tabular}{|c|c|c|c|c|c|c|c|c|}
\hline \multicolumn{3}{|c|}{ Category } & \multirow{2}{*}{$\begin{array}{c}\begin{array}{c}\text { House } \\
\text { holds }\end{array} \\
20\end{array}$} & \multirow{2}{*}{$\begin{array}{c}\text { Total } \\
358.4 \\
(100.0)\end{array}$} & \multirow{2}{*}{$\begin{array}{c}\begin{array}{c}\text { Household } \\
\text { Avg. }\end{array} \\
17.9\end{array}$} & \multirow{2}{*}{$\begin{array}{c}\begin{array}{c}\text { High } \\
\text { temperature }\end{array} \\
\begin{array}{c}103.6 \\
(28.9)\end{array}\end{array}$} & \multirow{2}{*}{$\begin{array}{c}\begin{array}{c}\text { Medium } \\
\text { temperature }\end{array} \\
\begin{array}{c}25.9 \\
(7.2)\end{array}\end{array}$} & \multirow{2}{*}{$\begin{array}{c}\text { Low } \\
\text { temperature }\end{array}$} \\
\hline \multirow{17}{*}{$\begin{array}{l}\text { Hwa- } \\
\text { sung }\end{array}$} & \multirow{6}{*}{ Age } & Total & & & & & & \\
\hline & & 30's & 2 & 42.0 & 21.0 & 26.0 & 5.0 & 11.0 \\
\hline & & 40's & 5 & 121.0 & 24.2 & 45.5 & 7.0 & 68.5 \\
\hline & & 50's & 6 & 142.4 & 23.7 & 26.6 & 10.8 & 105.0 \\
\hline & & 60's & 4 & 40.5 & 10.1 & 3.0 & 3.1 & 34.4 \\
\hline & & Over 70 & 3 & 12.5 & 4.2 & 2.5 & - & 10.0 \\
\hline & \multirow{6}{*}{$\begin{array}{c}\text { Farming } \\
\text { area }\end{array}$} & No land & 2 & 104.0 & 52.0 & 16.0 & 8.0 & 80.0 \\
\hline & & Less than 0.5 ha & 1 & 3.5 & 3.5 & - & - & 3.5 \\
\hline & & 0.5-1.0ha & 2 & 21.0 & 10.5 & 7.5 & - & 13.5 \\
\hline & & 1.0-1.5ha & 1 & 6.4 & 6.4 & 1.5 & - & 4.9 \\
\hline & & 1.5-2.0ha & 5 & 35.0 & 7.0 & 4.5 & 4.0 & 26.5 \\
\hline & & More than 2.0 ha & 9 & 188.5 & 20.9 & 74.1 & 13.9 & 100.5 \\
\hline & \multirow{5}{*}{$\begin{array}{c}\text { Number } \\
\text { of oak } \\
\operatorname{logs}\end{array}$} & Less than 10,000 & 11 & 67.4 & 6.1 & 10.1 & 5.9 & 51.4 \\
\hline & & $10,000-20,000$ & 3 & 43.0 & 14.3 & 9.5 & 2.0 & 31.5 \\
\hline & & $20,000-30,000$ & 3 & 74.5 & 24.8 & 21.0 & 13.0 & 40.5 \\
\hline & & $30,000-40,000$ & 1 & 38.0 & 38.0 & 25.0 & 5.0 & 8.0 \\
\hline & & More than 40,000 & 2 & 135.5 & 67.8 & 38.0 & - & 97.5 \\
\hline $\begin{array}{l}\text { Yong } \\
\text {-in }\end{array}$ & & Total & 13 & $\begin{array}{c}309.0 \\
(100.0)\end{array}$ & 23.8 & - & $\begin{array}{l}298.8 \\
(96.7)\end{array}$ & $\begin{array}{c}10.2 \\
(3.3)\end{array}$ \\
\hline
\end{tabular}


Farmers purchased strains of mushrooms from the National Forestry Cooperatives Federation and private sources, and reported loss and damages caused by the quality of strains. While there is no intervention to prevent loss and damages associated with strains, suppliers of strains and mushroom growers blame each other although there are some suppliers guarantee the compensation for any loss and damage caused by their strains.

The total oak mushroom production was $193,000 \mathrm{~kg}$ in Hwasung with an average household of 11,000 kg. By age group, oak mushroom production was higher in householders in their 50's showing an average output of $39,000 \mathrm{~kg}$. Those without their own farming land and those who had more than 40,000 oak logs produced larger quantities of mushrooms than the average output per household. Of the total production, 40\% was exported and the remaining 60\% was consumed domestically. The total oak mushroom production was
$154,000 \mathrm{~kg}$ with an average household of 7,000 kg. An average household production was $13,000 \mathrm{~kg}$ in householders in their 40's and 8,000 kg in householders in their 60's. Those without their own farming land and those who had 30,000 to 40,000 oak logs had larger quantities of mushrooms than the average production per household. Of the total output, 4\% was exported and the remaining 96\% was consumed domestically (Table 10). The Gyeonggi Provincial Government set up an Exporting Association for Oak Mushroom in 2000 to boost exports of oak mushrooms despite the fact that exporting was not profitable as much as domestic sales. But exports of oak mushroom should be promoted as a means of preventing a steep price falling in the domestic market and exports would benefit farmers in the long term by increasing demand. Every mushroom grower based in Gyeonggi Province is a member of the association. The difference in export results between Hwasung and Yongin was mainly because members in

Table 10. Oak mushroom production and distribution

Unit: thousand

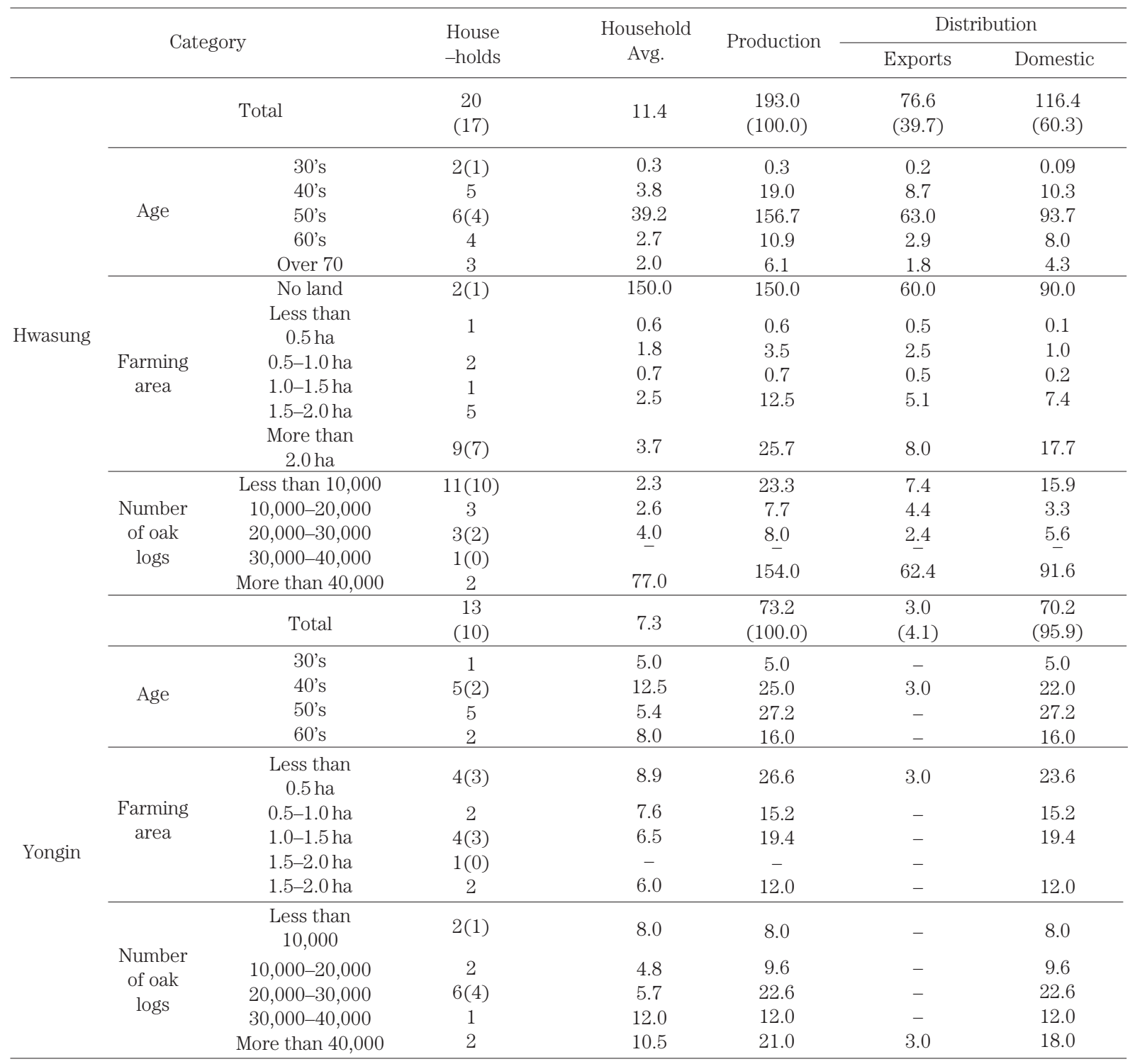

Note: 1) Figure in a parenthesis indicates a composition ratio (\%)

2) Three households in Yongin did not reveal their mushroom quantities so not included in the calculation 
Hwasung joined their efforts to increase exports of mushrooms and because members in Yongin were less enthusiastic about exporting due to various reasons such as higher domestic prices. In addition, fresh oak mushrooms are exported because dried mushrooms are not much demanded in foreign countries and more costly.

The average number of oak logs was 18,000 per household in Hwasung, but mushroom growers plan to have oak logs of 15,000 on average, signaling a decline in their mushroom cultivation in the future. However, those in their 40's plan to double the scale of mushroom production and the other age groups except those in their 30's plan to increase their mushroom production volume. By production scale, a large number of mushroom farmers plan to increase their mushroom cultivation, and of 20 households, 15 have a plan to expand wooden trays cultivation. Although many mushroom farmers want to use wooden trays for culture, the lack of logs pose an obstacle for them.

In Yongin, the average number of oak logs was 24,000 per household in Yongin, and mushroom farmers plan to increase their production volume to 31,000 units on average. Thus, their plan for an increase in mushroom production volume stands in contrast to a reduction in production volume planned by farmers in Hwasung. It was found that the majority of householders in their 40's and 50's, along with other age groups except the 60's age group, have plan for the increase in mushroom cultivation. There was no household who is interested in using wooden trays for culture because mushroom growers witnessed failures of their neighboring farmers who used wooden trays for culture on a trial basis (Table 11). The Gyeonggi Provincial Government set asided U\$1.14 billion won in 2006 for modernizing mushroom cultivation facilities and improv-

Table 11. Plans for mushroom cultivation and the use of wooden trays

Unit: thousand

\begin{tabular}{|c|c|c|c|c|c|c|c|c|}
\hline & \multicolumn{2}{|c|}{ Category } & \multirow[t]{2}{*}{ Households } & \multirow{2}{*}{$\begin{array}{l}\text { Current Avg. } \\
\text { household }\end{array}$} & \multirow{2}{*}{$\begin{array}{l}\text { Planned Avg. } \\
\text { household }\end{array}$} & \multicolumn{3}{|c|}{$\begin{array}{l}\text { Plan for the Use of Wooden trays } \\
\text { for culture (household) }\end{array}$} \\
\hline & & & & & & Total & Yes & No \\
\hline \multirow{18}{*}{ Hwasung } & & Total & $\begin{array}{c}20 \\
(10)\end{array}$ & 17.9 & 14.7 & 20 & 1 & 5 \\
\hline & \multirow{5}{*}{ Age } & 30's & $2(1)$ & 21.0 & 10.0 & 2 & 2 & - \\
\hline & & 40's & $5(3)$ & 24.2 & 56.7 & 5 & 4 & 1 \\
\hline & & 50 's & $6(3)$ & 23.7 & 26.7 & 6 & 5 & 1 \\
\hline & & 60’s & $4(2)$ & 10.1 & 14.0 & 4 & 3 & \\
\hline & & Over 70 & $3(1)$ & 4.2 & 6.0 & 3 & 1 & 1 \\
\hline & \multirow{6}{*}{$\begin{array}{l}\text { Farming } \\
\text { area }\end{array}$} & No land & $2(1)$ & 52.0 & 40.0 & 2 & 2 & 2 \\
\hline & & Less than 0.5 ha & $1(0)$ & 3.5 & - & 1 & - & - \\
\hline & & 0.5-1.0 ha & 2 & 10.5 & 8.0 & 2 & 2 & 1 \\
\hline & & $1.0-1.5 \mathrm{ha}$ & 1 & 6.4 & 30.0 & 1 & 1 & - \\
\hline & & 1.5-2.0 ha & $5(3)$ & 7.0 & 12.7 & 5 & 4 & - \\
\hline & & More than 2.0 ha & $9(3)$ & 20.9 & 56.7 & 9 & 6 & 1 \\
\hline & \multirow{5}{*}{$\begin{array}{c}\text { Number } \\
\text { of oak } \\
\operatorname{logs}\end{array}$} & Less than 10,000 & $11(5)$ & 6.1 & 14.8 & 11 & 7 & 3 \\
\hline & & $10,000-20,000$ & $3(2)$ & 14.3 & 15.0 & 3 & 3 & 4 \\
\hline & & $20,000-30,000$ & $3(2)$ & 24.8 & 45.0 & 3 & 2 & 1 \\
\hline & & $30,000-40,000$ & $1(0)$ & 38.0 & - & 1 & 1 & - \\
\hline & & More than 40,000 & $2(1)$ & 67.8 & 100.0 & 2 & 2 & - \\
\hline & & Total & 13 & 23.8 & 31.2 & 13 & - & 13 \\
\hline \multirow{14}{*}{ Yongin } & \multirow{4}{*}{ Age } & 30 's & 1 & 27.0 & 30.0 & 1 & - & 1 \\
\hline & & 40 's & 5 & 19.8 & 29.0 & 5 & - & 5 \\
\hline & & 50 's & 5 & 27.0 & 40.0 & 5 & - & 5 \\
\hline & & 60 's & 2 & 19.5 & 15.0 & 2 & - & 2 \\
\hline & \multirow{5}{*}{$\begin{array}{l}\text { Farming } \\
\text { area }\end{array}$} & Less than 0.5 ha & 4 & 32.4 & 47.5 & 4 & - & 4 \\
\hline & & 0.5-1.0 ha & 2 & 22.8 & 27.0 & 2 & - & 2 \\
\hline & & $1.0-1.5 \mathrm{ha}$ & 4 & 23.3 & 26.3 & 4 & - & 4 \\
\hline & & $1.5-2.0 \mathrm{ha}$ & 1 & 6.0 & 20.0 & 1 & - & 1 \\
\hline & & $1.5-2.0 \mathrm{ha}$ & 2 & 13.0 & 18.0 & 2 & - & 2 \\
\hline & \multirow{5}{*}{$\begin{array}{c}\text { Number } \\
\text { of oak } \\
\text { logs }\end{array}$} & Less than 10,000 & 2 & 7.0 & 20.0 & 2 & - & 2 \\
\hline & & $10,000-20,000$ & 2 & 18.8 & 33.0 & 2 & - & 2 \\
\hline & & $20,000-30,000$ & 6 & 22.9 & 29.2 & 6 & - & 6 \\
\hline & & $30,000-40,000$ & 1 & 30.0 & 14.0 & 1 & - & 1 \\
\hline & & More than 40,000 & 2 & 45.0 & 55.0 & 2 & - & 2 \\
\hline
\end{tabular}

Note: 1) Figure in a parenthesis indicates a composition ratio (\%)

2) Three households in Yongin did not reveal their mushroom quantities so not included in the calculation 
ing productivity and competitiveness of mushrooms. The local government will allocate 500 million won to financing the construction of facilities designed to promote sawdust-based culture (Gyeonggi Province, 2006).

\section{CONCLUSION}

1. In Hwasung City, those in their 60's was the largest group, constituting $25 \%$ of total members of all households, and an average age of householders was 55 years. In Yongin City, those in their 50's were the largest group comprising $28 \%$ of total members, and an average age of householders was 51 years. In Hwasung, an average farming area was 2.7 ha, compared to 0.8 ha in Yongin.

2. The household income was 48 million won on average in Hwasung, 43 million on average in Yongin. Oak mushroom production contributed to $80 \%$ of the income in Yongin, which is higher than 60\% in Hwasung.

3. Of 20 households in Hwasung, 11 cited mushroom cultivation and 9 cited agricultural farming as the major source of income. In Yongin, of 13 households, 12 said mushroom cultivation would become a major source of income in the future. Of 33 households in total, 22 plan to expand their farming area in the hope that they increase the scale of mushroom production.

4. A larger number of mushroom farmers purchase logs rather than directly obtain them in the forest. The low temperature type of mushrooms accounted for $64 \%$ in Hwasung, but the medium temperature type of mushrooms accounted for $96 \%$ in Yongin.

5. The average number of oak logs was 17,900 per household in Hwasung and 23,800 in Yongin. But the average oak mushroom production was $11.400 \mathrm{~kg}$ in Hwasung and $7,300 \mathrm{~kg}$ in Yongin. The production volume is lower in Yongin despite the number of logs is larger. About $40 \%$ of total output was exported in Hwasung, but almost all mushrooms (96\%) produced in Yongin are sold domestically.

6. While the majority of mushroom farms had intention to increase the scale of production and 15 out of 20 households are interested in using wooden trays for mushroom cultivation in Hwasung, and few farmers had the same interest in Yongin.

The following are the challenges found by reviewing the results of this study.

1. Considering differences in mushroom production among farmers, regardless of age and production scale, development and introduction of optimized cultivation techniques is imminent.

2. Financial support needed to be provided for mushroom farmers growing low temperature type of mushrooms due to high energy expenditures during winter

3. Insurance coverage is needed for mushroom farmers as a means of recovering damages caused by natural disasters such as heavy snow. At the same time, supports for equipments such as selector, refrigerator and refrigerator vehicles can be considered.

4. A stable supply system is required to prevent loss and damages caused by unhealthy strains and increase the spread of superior mushroom strains.

5. Wooden trays cultivation is recommended to compete with Chinese sawdust-based mushroom because it requires less labor and offers high productivity. But farmers' response to this method is tepid. Effects of wooden trays mushroom cultivation can be demonstrated through the model where farmers use the cultivation method on a trial basis.

6. Various supports need to be provided at the central and provincial government levels to boost exports of oak mushrooms.

\section{REFERENCES}

Gyeonggi Province 2005. Status of oak mushroom cultivator by person 2004

Gyeonggi Privince 2006. Policy of forest land. 510-512

Kang, C. Y et al., 2005 Present Situation and Mushroom Industry. Korea Rural Economic Institute

Korea Forest Research Institute. 2004 Recent state of mushroom production

Korea Forest Service 2005 Statistical yearbook offorestry

Korea Forest Service 2006 Export and import statistics on forest products

Lee, Y. S. 1996 Promotion Policy for Mushroom Industry. s

Ministry of Agriculture and Forestry. 2005 Statistics of Agriculture and Forestry 